\title{
KEWENANGAN PEMERINTAH DAERAH BIDANG PERTANAHAN DI ERA OTONOMI DAERAH
}

\author{
Musleh Herry \\ Fakultas Syari'ah UIN Maulana Malik Ibrahim Malang \\ Email:muslehherry@Yahoo.com
}

\begin{abstract}
Abstrak
Since the reformation era, the government made the revolution in government administration to develop Indonesia. One of the revolutions is the issuance of Law no. 32 of 2004 on Regional Government; the authority of land is one of the law components. Previously, the authority of land is centered in the central government. Conversely, through the Article 10 paragraph (3) of Law No. 32 of 2004 on regional autonomy, the authority of the land sector should be submitted to the local government for its more understanding about the land nowadays. The transfer of authority is one of development step in Law aspect in Indonesia.

Sejak era reformasi bergulir, pemerintah melakukan revolusi dibidang administrasi pemerintahan guna memajukan Negara Indonesia. Salah satu revolusi yang terjadi adalah dengan dikeluarkannya Undang-undang No. 32 Tahun 2004 tentang Pemerintahan Daerah, antara lain dibidang pertanahan. Semula kewenangan bidang pertanahan ini urusannya berada di pemerintah pusat. Namun di era reformasi ini melalui Pasal 10 ayat (3) UU No. 32 tahun 2004 tentang otonomi daerah, kewenangan bidang pertanahan sudah seharusnya diserahkan kepada pemerintah daerah yang lebih mengetahui kondisi pertanahan tersebut. Pengalihan kewenangan tersebut merupakan salah satu bentuk dari langkah pembangunan di bidang hukum di Indonesia.
\end{abstract}

Kata Kunci: Kewenangan, Pemerintah, Pertanahan dan Otonomi

Pembangunan bangsa Indonesia pada masa Orde Baru secara keseluruhan menunjukkan kemajuan yang pesat, khususnya pembangunan di Pusat karena adanya dorongan sentralisasi yang begitu kuat terhadap daerah, sehingga mengakibatkan pembangunan daerah tidak begitu berkembang. Terlihat dengan tidak diberikannya kesempatan yang memadai bagi daerah untuk mengurus rumah tangganya sendiri. ${ }^{1}$

Ketergantungan pemerintah daerah yang tinggi kepada pemerintah pusat

1 Colin MacAndrews dan Ichlasul Amal, Hubungan Pusat-Daerah dalam Pembangunan (Jakarta: RajaGrafindo Persada, 2004), h. 8. sebagai akibat paradigma rezim Orde Baru yang menjadikan kebijakan otonomi daerah sebagai instrumen sentralisasi, eksploitasi, dan penyeragaman atas daerah yang sangat beragam. Hal ini berimplikasi pada ketidak-jelasan arah otonomi daerah, dan menciptakan ketergantungan yang tinggi bagi pemerintah daerah dan pemerintah daerah tidak memiliki kewenangan untuk mengelola dan mengatur daerahnya atau daerah kehilangan ruang gerak dalam melaksanakan otonominya. ${ }^{2}$

Gagasan otonomi daerah berangkat dari

2 Abdurrahman,Pengadaan Tanah Bagi Pelaksanaan Pembangunan Untuk Kepentingan Umum (Bandung. CitranAditya Bakti, 1994), h. 11. 
suatuasumsibahwa pemegangkewenangan bahkan pemegang hak untuk mengatur rumah tangga sendiri adalah pemerintahan. Sebagaimana yang diamanatkan dalam Undang-Undang Dasar 1945 Pasal 18 ayat (3) yaitu :

Pemerintah daerah provinsi, daerah kabupaten dan kota mengatur dan mengurus sendiri urusan pemerintahan menurut asas otonomi daerah dan tugas pembantuan

Selanjutnya amanat bahwa setiap daerah harus menyelenggarakan otonomi daerah dituangkan dalam Ketetapan MPR RI Nomor XV/MPR/1998 bahwa:

Penyelenggaraan Otonomi Daerah dilaksanakan dengan memberikan kewenangan yang luas, nyata dan bertanggung jawab kepada daerah secara proposional yang diwujudkan melalui peraturan, pembagian dan pemanfaatan sumber daya nasional yang berkeadilan, serta perimbangan keuangan pusat dan daerah

Dengan demikian dalam rangka mewujudkan amanat Ketetapan MPR di atas, kemudian pemerintah mensahkan dan mengundangkan Undang-undang UndangUndang Nomor 32 tahun 2004 tanggal 5 Oktober 2004 (LN RI tahun 2004 Nomor 125, TLN RI tahun 2004 Nomor 4437). Pelaksanaan otonomi daerah yang diatur dalam Undang-Undang Nomor 32 tahun 2004 didasarkan pula pada prinsip otonomi seluas-luasnya, nyata dan bertanggung jawab. Prinsip seluas-luasnya dalam arti daerah diberikan kewenangan mengurus dan mengatur semua urusan pemerintahan di luar yang menjadi urusan pemerintah yang ditetapkan dalam undang-undang.

Persoalan kewenangan pemerintah bidang pertanahan sejak bergulirnya era otonomi daerah, di satu sisi, otonomi daerah memberikan kewenangan kepada daerah untuk mengurus urusan rumah tangganya sendiri sesuai dengan kekhasan daerahnya masing-masing. Namun pada sisi yang lain, urusan bidang pertanahan masih tetap berada dalam kewenangan pemerintah.

Dengan adanya Undang-Undang No-

mor 32 tahun 2004 tentang Pemerintah Daerah maka pemerintah daerah diberi kewenangan untuk mengatur dan mengurus daerahnya sendiri sebagaimana dalam Pasal 1 butir 5 yang isinya adalah pemerintah pusat memberikan hak, wewenang dan kewajiban daerah otonom untuk mengatur dan mengurus sendiri urusan pemerintahan dan kepentingan masyarakat setempat. Hal ini sesuai dengan UndangUndang Dasar 1945 Pasal 18 ayat (5) yang menyatakan bahwa "Pemerintah daerah menjalankan otonomi yang seluas-luasnya, kecuali urusan pemerintahan yang oleh undang-undang ditentukan sebagai urusan pemerintah pusat".

Dampak yang ditimbulkan dengan adanya ketidak serasian pengaturan kewenangan bidang pertanahan di daerah lebih banyak bersifat lokal. Oleh karena seringkali pemerintah pusat dalam membuat kebijakan di bidang pertanahan tidak menjangkau secara detail setiap permasalahan pertanahan yang ada di daerah dan pemerintah pusat kurang mempertimbangkan kepentingan daerah dengan adanya kewenangan di bidang pertanahan masih tetap berada di pemerintah pusat (sentralistik).

Dampak lain yang ditimbulkan dari kewenangan pertanahan tetap mejadi kewenangan pemerintah pusat, misalnya masalah pendaftaran tanah. Pengaturan masalah pendaftaran tanah dimulai sejak tahun 1960 (PP No. 10 tahun 1960) sampai sekarang dengan ketentuan Peraturan Pemerintah No. 24 tahun 1997 tentang Pendaftaran Tanah, tetap saja tidak menunjukkan keberhasilan, bahkan sampai sekarang masih banyak rakyat Indonesia yang belum mendaftarkan tanah serta banyak terdapat sengketa pertanahan yang disebabkan program pendaftaran tanah tersebut.

Dengan demikian, bahwa tidak selamanya dan semuanya kewenangan bidang pertanahan lebih baik dan lebih menguntungkan rakyat daerah jika tetap menjadi urusan pemerintah pusat, bahkan pemerintah daerah yang menanggung beban be- 
rat untuk menyelesaikan masalah sebagai akibat dari permasalahan yang ditimbulkan dari urusan pertanahan tersebut.

Pedelegasian kewenangan bidang pertanahan kepada pemerintah daerah, terlihat dalam ketentuan Peraturan Pemerintah No. 38 tahun 2007 tentang Pembagian Urusan Pemerintahan antara Pemerintah, Pemerintah Daerah Provinsi, dan Pemerintah Daerah Kabupaten/Kota dalam Pasal 2 ayat (4) dan Pasal 7 ayat (2). Pasal 2 ayat (4) huruf (i) yang dimaksud adalah urusan pemerintahan sebagaimana dimaksud pada ayat (3) terdiri atas 31 (tiga puluh satu) bidang urusan pemerintahan diantaranya pertanahan "bukan" pelayanan pertanahan.

Namun pelimpahan wewenang urusan pemerintahan di bidang pertanahan ini tidak dapat dilaksanakan karena terganjal oleh beberapa peraturan yang isinya kembali mensentralisasi bidang pertanahan menjadi kewenangan pemerintah pusat. Bahkan melalui Keputusan Presiden No, 34 tahun 2003 pemerintah menyatakan bahwa "sebagian" kewenangan pemerintah pusat di bidang pertanahan dilimpahkan kepada daerah, namun, keberadaan Badan Pertanahan Nasional (BPN) tidak dibubarkan tetapi tetap diberi kewenangan untuk menangani bidang pertanahan sampai pada yang bersifat lokal. ${ }^{3}$ Dengan diterbitkannya Peraturan Presiden No. 10 tahun 2006 tentang Badan pertanahan Nasional (BPN) yang memberi kewenangan penuh kepada Badan Pertanahan Nasional (BPN) yang tercermin dalam Pasal 2 Peraturan Presiden tersebutyang menyebutkan bahwa “Badan Pertanahan Nasional mempunyai tugas pemerintahan di bidang pertanahan secara nasional, regional dan sektoral".

Permasalahan yang mendasar dalam kewenangan pemerintah dan pemerintah daerah di bidang pertanahan di era otonomi daerah ini adalah kewenangan bidang pertanahan belum diserahkan ke-

3 Harian Jawa Pos, Pemerintah Pertahankan Keberadaan Kantor Badan Pertanahan Nasional di Daerah (Surabaya: 19 Juni 2003), h. 11. pada pemerintah daerah, pada hal jika kewenangan bidang pertanahan tersebut akan lebih baik jika diberikan kepada pemerintah daerah berdasarkan kreterian pemberian kewenangan secara efisien akan lebih berguna atau menfaat bagi daerah untuk mensejahterakan rakyat daerah melalui pengaturan tanah-tanah yang dapat dikelola rakyat daerah. Selain pemerintah daerah lebih mengetahui kebutuhan secara nyata rakyatnya akan tanah yang ada di daerah dan kewenangan bidang pertanahan merupakan sumber pendapatan bagi daerah yang dapat digunakan untuk lebih mensejahterakan rakyat daerahnya.

\section{Kebijakan Pemerintah Terhadap Kewe- nangan Pemerintah Daerah di Bidang Pertanahan}

\section{Kebijakan pertanahan nasional}

Kebijakan pertanahan nasional yang dirumuskan dalam Pasal 33 ayat (3) UUD 1945 didasarkan pada konsepsi bahwa semua tanah adalah tanah bangsa Indonesia sebagai Karunia Tuhan Yang Maha Esa, yang penguasaannya ditugaskan kepada negara untuk digunakan bagi sebesar-besarnya kemakmuran rakyat. Hak menguasai oleh negara yang pada intinya dirumuskan dalam Pasal 2 UUPA memberikan kewenangan untuk mengatur dan menetapkan berbagai segi penguasaan tanah yang sejak semula menurut sifatnya selalu dianggap sebagai tugas pemerintah pusat. $^{4}$

Pengaturan dan penetapan tersebut yang meliputi perencanaan peruntukan tanah, penguasaan dan perbuatan-perbuatan hukum mengenai tanah serta pendaftaran tanah, pelaksanaan ketentuan hukumnya pada asasnya selalu dilakukan oleh pemerintah pusat sendiri. Kalaupun ada pelimpahan kewenangan dalam pelaksanaannya, pelimpahan tersebut dilakukan dalam rangka dekosentrasi kepada pejabatpejabat pemerintah pusat yang ada di daerah ataupun kepada pemerintah daerah dalam

\footnotetext{
4 Hutagalung, Tebaran Pemikiran (Jakarta: Djambatanat
} 
rangka medebewind, bukan otonomi daerah. ${ }^{5}$

Karena pemberian otonomi tersebut berada dalam bingkai negara kesatuan, kebebasan untuk mengatur dan mengurus bidang pertanahan akan tetap dilakukan dalam rangka kebijakan dasar dan pokokpokok ketentuan hukum pertanahan yang berlaku nasional sebagai yang dinyatakan dari kata-kata "sesuai peraturan perundang-undangan". Sehubungan dengan itu, otonomi jelas tidak diartikan sebagai penyerahan pengaturan dan pengurusan segala segi masalah pertanahan sepenuhnya kepada daerah kabupaten dan kota masing-masing, tetapi ada kewenangan-kewenangan pengaturan halhal yang bersifat pokok dan umum, serta pembinaan pada pemerintah pusat terhadap pelaksaaan kewenangan otonomi tersebut oleh pemerintah daerah masingmasing. Dengan demikian, kendati daerah akan dan memang harus memerhatikan kepentingan dan aspirasi keserasian yang bersifat nasional.

Untukitu, diperlukansuatuketentuanperaturan perundang-undangan yang secara jelas mengatur kewenangan-kewenangan yang didelegasikan kepada pemerintah daerah. Dari materi muatan yang terdapat dalam UUD 1945, TAP MPR Nomor IX/2001 tentang Pembaruan Agraria dan Pengelolaan Sumber Daya Alam, UndangUndang Nomor 5 Tahun 1960 tentang Peraturan Dasar Pokok-Pokok Agraria, Undang-Undang Nomor 32 Tahun 2004 tentang Pemerintahan Daerah, Peraturan Pemerintah Nomor 38 Tahun 207 tentang Pembagian Urusan Pemerintahan Antara Pemerintah, Pemerintahan Daerah Provinsi, dan Pemerintahan Daerah Provinsi, dan Pemerintahan Daerah Kabupaten/Kota, kewenangan dari pusat meliputi hukum, kebijakan, pedoman mengenai pemberian hak-hak atas tanah, pendaftaran, landreform, dalam bentuk undang-undang, peraturan pemerintah maupun keputusan presiden. Sementara itu, kewenangan pemerintah daerah cukup pada pelayanan masyarakat

5 Hutagalung, Tebaran.,h. 40. dan pelaksanaan kebijakan yang dapat dituangkan dalam bentuk peraturan daerah maupun keputusan kepala daerah.

Pertimbangan pengurusan pertanahan menjadi kewenangan pemerintah pusat antara lain sebagai berikut: ${ }^{6}$ ) Seluruh wilayah Indonesia adalah kesatuan tanah air dari seluruh rakyat Indonesia yang bersatu sebagai bangsa Indonesia (Pasal 1 ayat 1 UUPA).Ketentuan ini merupakan dasar kenasionalan dalam pengelolaan agraria. Sebagaimana dalam penjelasan umum angka II, konsep kenasionalan menghendaki bumi, air, dan ruang angkasa dalam wilayah Republik Indonesia yang kemerdekaannya diperjuangkan oleh seluruh bangsa Indonesia selayakya menjadi hak dari bangsa Indonesia pula. 2) Seluruh bumi, air, dan ruang angkasa termasuk kekayaan alam yang terkandung di dalamnya adalah bumi, air, dan ruang angkasa bangsa Indonesia dan merupakan kekayaan nasional (Pasal 1 ayat 2 UUPA). Ketentuan ini mengandung makna bahwa sumber daya agraria merupakan kekayaan nasional.Adapun pengeolaannya harus memerhatikan kepentingan bangsa Indonesia secara keseluruhan tersebut. 3) Hubungan antara bangsa Indonesia dengan bumi, air dan ruang angkasa bersifat abadi (Pasal 1 ayat 3 UUPA).Ketentuan ini merupakan dasar dalam rangka pembinaan integrasi Negara Kesatuan Republik Indonesia (NKRI).Disadari bahwa bangsa Indonesia mempunyai ikatan yang sangat erat dengan tanahnya. Hal ini disebabkan tanah merupakan komponen yang penting bagi penyelenggaraan hidup dan kehidupannya.

\section{Kebijakan pertanahan berdasarkan undang-undang nomor 5 tahun 1960 tentang peraturan dasar pokok-pokok agraria}

Keberadaan Undang-Undang Nomor 5 Tahun 1960 tentang Peraturan Dasar Pokokpokok Agrara sebagai undang-undang pokok tidak saja secara tegas dinyatakan dalam judul undang-undangnya, tetapi juga

6 Hutagalungtifebaran.,h. 42-43. 
diperlihatkan dalam pasal demi pasal yang mengatur bidang agraria tersebut. Kendati udang-undang secara formal merupakan suatu peratuaran yang dibuat oleh pemerintah dengan persetujuan Dewan Perwakilan Rakyat, tetapi mengingat sifatnya sebagai peraturan dasar, dalam undang-undang tersebut hanya dimuat mengenai asas-asas dan garis besarnya saja.

Setidaknya terdapat tiga hal utama yang menjadi tujuan diterbitkannya UndangUndang Pokok Agraria, yaitu sebagai berikut. $^{7}$ a) Meletakkan dasar-dasar bagi penyusunan hukum agraria nasional, yang akan merupakan alat untuk membawakan kemakmuran, kebahagiaan dan keadilan bagi negara dan rakyat, terutama rakyat tani, dalam rangka masyarakat yang adil dan makmur. (1) Negara tidak bertindak sebagai pemilik tanah, melainkan bertindak selaku badan penguasa. Kata "dikuasai" bukan berarti "dimiliki", namunmerupakan pengertian yang memberi wewenang kepada negara sebagai organisasi tertinggi untuk mengatur dan menyelenggarakan perutukan, penggunaan, persediaan dan pemeliharaannya, menentukan dan mengatur hak-hak yang dapat dipunyai atas (bagian dari) bumi, air dan ruang angkasa itu, menentukan dan mengatur hubunganhubungan hukum yang mengenai bumi, air dan ruang angkasa. Semuanya itu dengan tujuan untuk mencapai sebesar-besarnya kemakmuran rakyat dalam rangka masyarakat yang adil dan makmur. 2) Pengakuan adanya hak rakyat sepanjang hak tersebut menurut kenyataannya memang masih ada pada masyarakat hukum yang bersangkutan dan harus tunduk pada kepentingan nasional dan Negara. 3) Semua hak atas tanah mempunyai fungsi social. Hal ini bermakna bahwa penggunaan tanah harus disesuaikan dengan keadaannya dan sifat haknya sehingga bermanfaat baik bagi kesejahteraan dan kebahagiaan yang mempunyainya maupun bermanfaat bagi masyaraka dan negara. 4) Sesuai dengan

7 Undang-Undang No. 5 Tahun 1960 TTg UUPA.dan penjelasan, h. 10 . asas kebangsaan hanya warga negara Indonesia saja yang dapat mempunyai hak milik atas tanah. Hak milik tidak dapat dimiliki oleh orang asing dan pemindahan hak milik kepada orang asing dilarang. Orang-orang asing dapat mempunyai tanah dengan hak pakai yang luasnya terbatas.5) Tiap-tiap warga negara Indonesia, baik laki-aki maupun wanita mempunyai kesempatan yang sama untuk memperoleh sesuatu hak atas tanah serta untuk mendapat manfaat dan hasilnya, baik bagi diri sendiri maupun keluarganya. Untuk itu, perlu diadakan perlindungan bagi golongan warga negara yang kuat kedudukan ekonominya. 6) Tanah pertanian harus dikerjakan atau diusahakan secara akif oleh pemiliknya sendiri. Agar semboyan ini dapat diwujudkan, perlu diadakan ketentuan-ketentuan lainnya.7) Untuk mencapai apa yang menjadi cita-cita bangsa dan negara dalam bidang agraria, perlu adanya suatu rencana mengenai peruntukan, penggunaan dan persediaan bumi, air dan ruang angkasa untuk pelbagai kepentingan hidup rakyat dan negara. (b) Meletakkan dasar-dasar untuk mengadakan kesatuan dan kesederhanaan dalam hukum pertanahan. (c) Meletakkan dasar-dasar untuk memberikan kepastian hukum mengenai hak-hak tanah bagi rakyat seluruhnya, sesuai dengan Pasal 23, 32, dan 38 UUPA ditujukan kepada para pemegang hak yang bersangkutan, dengan maksud agar mereka mereka memperoleh kepastian tentang haknya. Sementara itu, Pasal 19 UUPA ditujukan kepada pemerintah sebagai suatu instruksi agar di seluruh wilayah Indonesia diadakan pendaftaran tanah yang bersifat "rechts kadaster", yang bertujuan menjamin kepastian hukum.

\section{Keputusan Kepala Badan Pertanahan Nasional Nomor 2 Tahun 2003}

Pasal 2 Keputusan Presiden Nomor 34 Tahun 2003 tentang Kebijakan Nasional di Bidang Pertanahan menyebutkan tentang bagian kewenangan pemerintah di bidang pertanahan yang dilaksanakan oleh peme-

(n) nitro $^{\text {PDF }^{\prime}}$ professional 
rintah kabupaten/kota. Kewenangan tersebut antara lain: pemberian izin lokasi; penyelenggaraan pengadaan tanah untuk kepentingan pembangunan; penyelesaian sengketa tanah garapan; penyelesaian masalah ganti kerugian dan santunan tanah untuk pembangunan; penetapan subjek dan objek redistribusi tanah serta ganti kerugian tanah kelebihan maksimum dan tanah absentee; penetapan dan penyelesaian masalah tanah rakyat; pemanfaatan dan penyelesaian tanah kosong; pemberian izin membuka tanah; perencanaan penggunaan tanah wilayah kabupaten/kota. ${ }^{8}$

Sebagai tindak lanjut dari Keputusan Presiden tersebut, ditetapka Keputusan Kepala Badan Pertanahan Nasional Nomor 2 Tahun 2003 tentang Norma dan Standar Mekanisme Ketatalaksanaan Kewenangan Pemerintah Pemerintah di Bidang Pertanahan yang Dilaksanakan oleh Pemerintah Kabupaten/Kota.Dalam Keputusan Kepala Badan Pertanahan Nasional Nomor 2 Tahun 2003 tersebut diatur secara rinci tentang kewenangan bidang pertanahan yang dilaksanakan pemerintah kabupaten/kota.

\section{Kewenangan Pemerintah Daerah di Bidang Pertanahan di Era Otonomi Daerah}

\section{Kewenangan pemerintahan}

Masalah tanah adalah masalah yang sangat menyentuh keadilan karena sifatnya yang langka dan terbatas serta merupakan kebutuhan dasar setiap manusia. Memang tidak mudah untuk merancang suatu kebijakan pertanahan yang dirasakan adil oleh semua pihak. Suatu kebijakan yang memberikan kelonggaran yang lebih besar kepada sebagian kecil masyarakat dapat dibenarkan apabila diimbangi dengan kebijakan serupa yang ditujukan kepada kelompok lainyang lebih besar. Dengan demikian, selalu ada kebijakan yang berfungsi untuk mengoreksi atau memulihkan keseimbangan tersebut.

Dalam merancang kebijakan di bi-

8 RepublikIndonesia, Keputusan Presiden tentang Kebijakan Nasional di Bidang Pertanahan(Jakarta: Pasal 2). dang pertanahan, tolok ukur yang lebih tepat adalah memberikan keadilan berdasarkan kebutuhan dan bukan berdasarkan kemampuan karena dalam peta penguasaan dan pemanfaatan tanah di Indonesia perhatian harus lebih banyak diberikan kepada mereka yang lebih membutuhkan yang diwakili oleh sebagian terbesar lapisan masyarakat.Harapan tersebut dihadapkan pada kebutuhan untuk melengkapi peraturan pelaksanaan UUPA, kebijakan pertanahan baik dalam hal penguasaan dan penatagunaan, hak atas tanah, pengukuran, dan pendaftaran tanah sebaiknya dirancang berdasarkan pola dengan urutan prioritas yang ditentukan berdasarkan pemenuhan kebutuhan masyarakat, tanpa mengabaikan perlunya diciptakan kebijakan yang menunjang perkembangan kebutuhan ekonomi yang dinamis serta investasi oriented.

Urusan pemerintahan yang menjadi kewenangan Pemerintah meliputi politik luar negeri, pertahanan, keamanan, yustisia, moneter dan fiskal nasional, serta agama. Sementara itu yang menjadi kewenangan daerah terdiri dari urusan wajib dan urusan pilihan.Urusan pemerintahan wajib adalah urusan pemerintahan yang wajib diselenggarakan oleh Pemerintah Daerah yang terkait dengan pelayanan dasar ( $b a-$ sic services) bagi masyarakat, seperti pertanahan, pendidikan dasar, kesehatan, lingkungan hidup, perhubungan, kependudukan, dan sebagainya. Urusan pemerintahan yang bersifat pilihan adalah urusan pemerintahan yang diprioritaskan oleh Pemerintah Daerah untuk diselenggarakan yang terkait dengan upaya mengembangkan potensi unggulan (core competence) yang menjadi kekhasan daerah. Urusan pemerintahan di luar urusan wajib dan pilihan yang diselenggarakan oleh Pemerintah Daerah, sepanjang menjadi kewenangan daerah yang bersangkutan tetap harus diselenggarakan oleh Pemerintah Daerah yang bersangkutan.

Tetapi, mengingat terbatasnya sumber

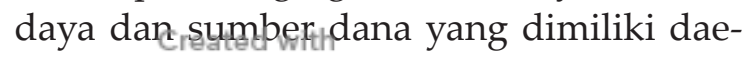


rah, prioritas penyelenggaraan urusan pemerintahan difokuskan pada urusan wajib dan urusan pilihan yang benar-benar mengarah pada penciptaan kesejahteraan masyarakat, yang disesuaikan dengan kondisi, potensi, dan kekhasan daerah yang bersangkutan.

Berdasarkan Peraturan Pemerintah Nomor 38 Tahun 2007 tentang Pembagian Urusan Pemerintahan antara Pemerintah, Pemerintahan Daerah Provinsi, dan Pemerintahan Daerah Kabupaten/Kota, memiliki kewenangan yang terkait dengan pelayanan dasar (basic service) terhadap 9 (sembilan) kewenangan yang juga diakomodir dalam Keputusan Presiden Nomor 34 Tahun 2003 tentang Kebijakan Nasional di Bidang Pertanahan, yaitu; 1) Izin Lokasi, 2) Pengadaan Tanah Untuk Kepentingan Umum, 3) Penyelesaian Sengketa Tanah Garapan, 4) Penyelesaian Masalah Ganti Kerugian dan Santunan Tanah Untuk Pembangunan, 5) Penetapan Subjek dan Objek Redistribusi Tanah, serta Ganti Kerugian Tanah Kelebihan Maksimum dan Tanah Absente, 6) Penetapan Tanah Ulayat, 7) Pemanfaatan dan Penyelesaian Masalah Tanah Kosong, 8) Izin Membuka Tanah, 9) Perencanaan Penggunaan Tanah Wilayah Kabupaten / Kota.

Adapun kewenangan Pemerintah Provinsi adalah terkait dengan kewenangan yang bersifat lintas Kabupaten / Kota, sedangkan yang menjadi kewenangan Pemerintah Pusat di bidang pertanahan terkait dengan penetapan mengenai norma, standar, prosedur, dan kriteria, termasuk pembinaan, pengendalian dan monitoring terhadap pelaksanaan kewenangan tersebut.

Dari uraian tersebut, semoga hal ini dapat dijadikan bahan pengambilan kebijakan lebih lanjut terkait dengan keberadaan instansi vertikal yang selama ini masih eksis di daerah dan masih tekun mengerjakan urusan tertentu saja (yang ada fulusnya tentu, sedang yang tidak ada fulusnya selalu buang muka dan pura-pura tidak tahu) yang bukan merupakan kewenangannya yaitu Kantor Pertanahan dan Kanwil Per- tanahan, mengingat peran mereka tersebut sesungguhnya telah tereduksi. Coba kita cermati kembali kewenangan masing-masing sehingga kewenangan itu dapat kembali pada khitoh-nya dan tidak bersikukuh memegangnya karena alasan uang.

\section{Kewenangan pemerintah daerah di bidang pertanahan}

Sesuai dengan UUD 1945 sebelum dirubah, pemerintahan daerah terdiri atas daerah besar dan daerah kecil. Daerah besar adalah pemerintah provinsi sedangkan daerah kecil adalah pemerintah kabupaten/ kota dan desa. Pertanyaan yang muncul adalah apakah daerah kecil (kabupaten/ kota dan desa) merupakan bawahan daerah besar (provinsi) ? Dalam hal provinsi sebagai daerah otonom maka pemerintah kabupaten/kota bukanlah bawahan provinsi. Akan tetapi, dalam hal provinsi berkedudukan sebagai wilayah administrasi, maka pemerintah kabupaten/ kota merupakan sub-ordinat wilayah administrasi provinsi. Dengan demikian, dalam hal provinsi sebagai daerah otonom, maka pemerintah kabupaten/kota sebagai sesama daerah otonom. Hubungan provinsi dengan pemerintah kabupaten/kota sebagai sesama daerah otonom adalah hubungan "koordinasi". Jadi, bukan hubungan hierarki antara atasan dan bawahan sebagaimana UU No. 5 tahun 1974 yang lalu. Hubungan antara pemerintah provinsi dengan pemerintah pemerintah kabupaten/kota dapat dilihat pada bagan II di bawah ini:

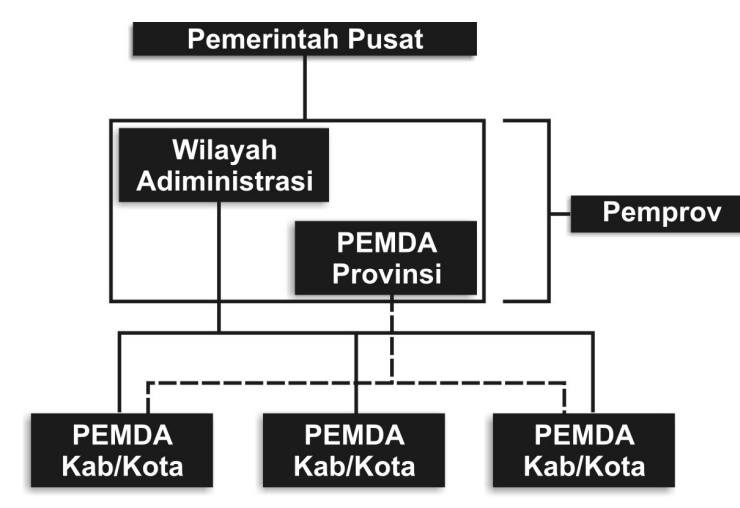

Bagan II:Hubungan Pemerintah Provinsi dengan Pemerintah Kabupaten/Kota. 
Garis putus-putus antara pemerintah daerah provinsi dengan pemerintah daerah kabupaten/kota menunjukkan hubungan koordinasi sesama daerah otonom. Sedangkan garis lurus yang diperlihatkan antara wilayah administrasi provinsi dengan pemerintah daerah kabupaten/kota menunjukkan hubungan hierarki.

Menurut Undang-Undang No.32 tahun 2004, kewenangan yang dimiliki pemerintah kabupaten/kota adalah sisa kewenangan pemerintah pusat dan pemerintah provinsi. Dengan demikian, pemerintah kabupaten/ kota memiliki kewenangan yang sangat besar. Artinya, bobot kewenangan terletak di pemerintah kabupaten/kota, karena itu urusan di bidang pertanahan merupakan sisa urusan pemerintah pusat sebagaimana tercantum dalam Pasal 10 ayat (3) UU No. 32 tahun 2004, yaitu :

Urusan pemerintahan yang menjadi urusan Pemerintah sebagaimana dimaksud pada ayat (1) meliputi: a. politik luar negeri; b. pertahanan; c. keamanan; d. Peradilan; e. moneter dan fiskal nasional; dan f. Agama

Dengan demikian, urusan pemerintahan selain yang tercantum dalam Pasal 10 ayat (3) tersebut merupakan urusan atau kewenangan pemerintah kabupaten/kota. Dengan kata lain, di sini terjadi pendelegasian kewenangan bidang-bidang pemerintahan yang merupakan sisa urusan wajib/kewenangan pemerintah pusat kepada pemerintah daerah kabupaten/kota. Oleh karena urusan pemerintahan di bidang pertanahan merupakan sisa dari kewenangan pemerintah pusat, maka kewenangan di bidang pertanahan seharusnya merupakan kewenangan delegasi dari pemerintah pusat. Berdasarkan pendelegasian kewenangan tersebut pemerintah daerah dapat berinisiatif membuat kewenangan sendiri berdasarkan kebutuhan daerahnya. Kewenangan yang dibuat sendiri oleh kabupaten/kota tersebt bukan berdasarkan pendekatan sektor, departemen, dan non departemen yang ada, akan tetapi berdasarkan pembidangan

kewenangan. Di sini, kabupaten/kota dapat membuat rincian kewenangan yang kemudian diagresikan sehingga menjadi kewenangan yang setara antar bidang.

Undang-undang Nomor 32 tahun 2004 menetapkan urusan pemerintahan pemerintah kabupaten/kota yang bersifat wajib dan pilihan. Dalam Pasal 14 ayat (1) menyebutkan bahwa Urusan pemerintahan yang bersifat wajib mencakup urusan-urusan yang berskala kabupaten/kota, yaitu; a) Perencanaan dan pengendalian pembangunan,b)Perencanaan, pemanfaatandan pengawasan tata ruang, c) Penyelenggaraan ketertiban umum dan ketenteraman masyarakat, d) Penyediaan sarana dan prasarana umum, e) Penanganan bidang kesehatan, f) Penyelenggaraan bidang pendidikan, g) Penanggulangan masalah sosial, h) Pelayanan bidang ketenagakerjaan, i) Fasilitas pengembangan koperasi, usaha kecil, dan menengah, j) Pengendalian lingkungan hidup, k) Pelayanan pertanahan, 1) Pelayanan kependudukan dan catatan sipil, m) Pelayanan administrasi umum pemerintahan, n) Pelayanan administrasi penanaman modal, o) Penyelenggaraan pelayanan dasar lainnya, p) Urusan wajib lainnya yang diamanatkan oleh peraturan perundang-undangan.

Adapun urusan pemerintah daerah kabupaten/kota yang bersifat pilihan meliputi urusan pemerintahan yang secara nyata ada dan berpotensi untuk meningkatkan kesejahteraan masyarakat sesuai dengan kondisi, kekhasan dan potensi unggulan daerah yang bersangkutan.

Sebagaimana halnya pemerintah provinsi, pemerintah kabupaten/kota juga menerima tugas pembantuan (medebewind) dari pemerintah pusat dan provinsi (sebagai daerah otonom). Tugas pembantuan yang diberikan pemerintah pusat kepada pemerintah daerah kabupaten/kota adalah kewenangan yang merupakan kompetansi pemerintah pusat yang meliputi tugas di bidang politik luar negeri, pertahanan, keamanan, peradilan, moneter dan fiskal 
nasional dan agama dan kewenangan lain, yaitu kebijakan tentang perencanaan nasioanal dan pengendalian pembangunan secara makro, dana perimbangan keuangan, sistem administrasi negara dan lembaga perekonomian negara, pembinaan dan pemberdayaan sumber daya manusia, pendayagunaan sumber daya alam serta teknologi yang strategis, konservasi dan standarisasi nasional, sebagaimana dimaksud dalam penjelasan Umum I PP No. 52 tahun 2001 tentang Penyelenggaraan Tugas Pembantuan. Sedangkan tugas pembantuan yang diberikan oleh pemerintah daerah provinsi kepada pemerintah daerah kabupaten/kota, meliputi sebagian tugas dalam pemerintahan yang bersifat lintas kabupaten/kota, serta sebagian tugas pemerintahan yang tidak atau belum dapat dilaksanakan oleh pemerintah kabupaten/ kota. ${ }^{9}$

Berdasarkan peraturan perundangundangan, hakekat tugas pembantuan yaitu sebagai berikut; 1) Tugas pembantuan adalah tugas membantu untuk menjalankan urusan pemerintahan dalam tahap implementasi kebijakan yang bersifat operasional baik bersifat fisik maupun non fisik, 2) Urusan pemerintahan yang ditugaspembantukan adalah yang menjadi kewenangan dari instansi yang menugaskannya, 3) Kewenangan yang dapat ditugaspembantukan adalah kewenangan yang bersifat atributif, sedangkan kewenangan yang bersifat delegatif tidak ditugaspembantukan kepada institusi lain, 4) Urusan pemerintah atau pemerintah daerah yang ditugaspembantukan tetap menjadi kewenangan dari institusi yang menugaskannya sesuai kebutuhan, 5) Kebijakan, strategi, pembiayaan, sarana dan prasarana serta sumber daya manusia disediakan oleh institusi yang menugaskannya, 6) Kegiatan operasionak sepenuhnya diserahkan pada institusi yang diberi penugasan, sesuai dengan situasi, kondisi serta kemampuannya, 7) Institusi yang menerima penugasan

${ }^{9}$ Hanif Nurcholis, Teori dan Praktek Pemerintahan dan otonomi Daerah (Jakarta:Grasindo, 2007),h. 175. diwajibkan melapor dan mempertanggung jawabkan mengenai urusan pemerintahan yang dikerjakannya kepada institusi yang menugaskannya. ${ }^{10}$

Oleh karena itu Guna menjamin keberhasilan implementasi tugas pembantuan tersebut, perlu dilakukan analisis terlebih dahulu terhadap kebutuhan biaya, sarana dan prasarana serta sumber daya manusia yangakan menjalankantugastersebut. Perlu pula disusun rencana tindakan (action plan) yang dijadikan pedoman bagi pemerintah daerah dalam proses pelaksanaannya. Analisis ini diperlukan dengan maksud agar pemerintah daerah dalam batas-batas tertentu memiliki kebebasan untuk menggunakan hak penolakan daerah terhadap pemberian tugas pembantuan oleh pemerintah pusat.

Berdasarkan ketentuan pembagian urusan atau kewenangan pemerintahan, sudah seharusnya kewenangan yang merupakan kompetansi pemerintah pusat dan pemerintah daerah provinsi inilah yang seharusnya menjadi tugas pembantuan pemerintah daerah, bukan pada kewenangan yang sudah menjadi kewenangan pemerintah daerah/kota, seperti halnya kewenangan dibidang pertanahan khususnya kewenangan dalam pengadaan tanah apalagi pengadaan tanah untuk kepentingan umum yang berada atau akan dipergunakan untuk pelaksanaan pembangunan di daerah.

Menurut peneliti di sinilah letak kerancuan pengaturan kewenangan pemerintahan di bidang pertanahan antara pemerintah pusat dengan pemerintah daerah. Terlihat jelas, ada keraguan pemerintah pusat dalam menentukan atau memberikan (mendelegasikan) kewenangan yang akan diberikan (didelegasikan) kepada pemerintah daerah kabupaten/kota, khususnya dibidang pertanahan. Seharusnya kewenangan dibidang pertanahan merupakan kewenangan atau menjadi urusan pe-

\footnotetext{
${ }^{10}$ Sadu Wasistiono, dkk, Memahami Asas Tugas Pembantuan: Pandangan Legalistik, Teoritik, dan Implementatif(Bandung: Fokusmefdia, 2006), h. 20.
} 
merintah daerah kabupaten/kota sesuai dengan amanat Pasal 10 ayat (3) UU No. 32 tahun 2004 tentang Pemerintahan Daerah. Kemudian kewenangan di bidang pertanahan tersebut diambangkan kembali jika dilihat dalam Pasal 14 ayat (1) UU No. 32 tahun 2004, dalam pasal tersebut pemerintah daerah kabupaten/kota hanya diberi tugas pembantuan yaitu pelayanan pertanahan. Padahalkewenangan dibidang pertanahan merupakan kewenangan yang berada di luar (sisa) kewenangan pemerintah pusat.

Jika dilihat dari hakekat tugas pembantuan di atas, maka kewenangan di bidang pertanahan seharusnya berada pada pemerintah daerah atau merupakan kewenangan pemerintah daerah. Oleh karena Urusan pemerintahan yang ditugas pembantukan adalah yang menjadi kewenangan dari instansi yang menugaskannya dan kewenangan yang bersifat atributif. Jadi, kewenangan ditugas pembantukan kepada pemerintah daerah seharusnya tugas pemerintah pusat yang berdasarkan Pasal 10 ayat (3) Undang-undang No. 32 tahun 2004 tentang Pemerintahan Daerah, karena tugas tersebut merupakan tugas atributif pe-

\section{DAFTAR PUSTAKA}

Abdurrahman. 1994.Pengadaan Tanah Bagi Pelaksanaan Pembangunan Untuk Kepentingan Umum. Bandung:Citra Aditya Bakti.

Colin MacAndrews dan Ichlasul Amal.2004. Hubungan Pusat-Daerah dalam Pembangunan. Jakarta: RajaGrafindo Persada.

Asshiddiqie, Jimly. 2000. Otonomi Daerah dan Peluang Investasi, Makalah pada seminar Otonomi Daearah, Government Confren, 29-30 September 2000, Jakarta.

Asshiddiqie, Jimly, Pengorganisasian Kekuasaan Legislatif dan Eksekutif, dalam Jurnal Keadilan, Vol.2 No.1 tahun 2002.

Hamid S. Attamimi, A. (Disertasi).1990. Peranan Keputusan Presiden Indonesia merintah pusat, bukan tugas yang berada diluar tugas yang diatur oleh Pasal 10 ayat (3) tersebut.

\section{Kesimpulan}

Berdasarkan pembahasan penelitian ini dapat disimpulkan sebagai berikut, bahwa; Pertama,Kebijakan yang mengatur kewenangan pemerintah daerah bidang pertanahan di era otonomi daerah, yaitu melalui; 1) Pasal 18 Undang-Undang Dasar $1945,2)$ Undang-Undang Nomor 5 Tahun 1960 tentang Peraturan Dasar Pokok-Pokok Agraria (UUPA), 3) Undang-undang Nomor 32 tahun 2004 tentang Pemerintahan Daerah, 4) Keputusan Kepala Badan Pertanahan Nasional Nomor 2 Tahun 2003 tentang Norma dan Standar Mekanisme Ketatalaksanaan Kewenangan Pemerintah di Bidang Pertanahan yang Dilaksanakan oleh Pemerintah Kabupaten/Kota. Kedua, Kewenangan pemerintah daerah bidang pertanahan di era Otonomi Daerah, sebagaimana diatur dalam Undang-undang Nomor 32 tahun 2004, diatur sebagai berikut; 1) Kewenangan Pemerintahan, 2) Kewenangan Pemerintah Daerah di Bidang Pertanahan.

dalam Penyelenggaraan Pemerintahan Negara.Jakarta:Fakultas Hukum UI.

Badudu, JS dan Sutan Muhammad Zen. 1994.Kamus Umum Bahasa Indonesia. Jakarta: Pustaka Sinar Harapan.

Biersttedt Robert dalam Miriam Budiardjo. 2009. Dasar-Dasar Ilmu Politik.Edisi revisi. Jakarta: Gramedia Pustaka Utama.

Budiardjo, Miriam. 2009.Dasar-Dasar Ilmu Politik, (edisi revisi).Jakarta:Gramedia Pustaka Utama.

Hutagalung, Tebaran Pemikiran.Jakarta: Djambatan.

Ibrahim, Johnny. 2007.Teori dan Metodologi Penelitian Hukum Normatif. Malang: Penerbit Bayumedia.

Nasution, S. 1996. Metode Penelitian natu-

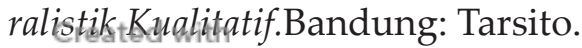


Nicolai, P. dalam Ridwan HR. 2007. Hukum Administrasi Negara. Jakarta: Raja Grafindo Persada.

Notonegoro, dalam Maria S.W. Soemardjono. 2001. Kebijakan Pertanahan Antara Regulasi dan Implementasi.Jakarta: Penerbit KOMPAS.

Nurjaman, Asep, dalam Andi A. Malarangeng, dkk. 2001.Otonomi Daerah Perspektif Teoritis dan Praktis. Malang: Bigrif.
Nurcholis, Hanif. 2007. Teori dan Praktek Pemerintahan dan otonomi Daerah. Jakarta: Grasindo.

Kamus Besar Bahasa Indonesia. 1995. Departemen Pendidikan dan Kebudayaan \& Balai Pusataka. Jakarta.

Undang-undang No. 32 tahun 2004 tentang Pemerintahan Daerah

Undang-undang No. 5 tahun 1960 tentang Ketentuan Dasar Pokok-Pokok Agraria. 